\title{
The Safety of Areca Seed Ethanolic Extract as Potential Chemopreventive Agent is Proven by Acute Toxicity Test
}

\author{
Sri Handayani ${ }^{1 *}$, Riris Istighfari Jenie ${ }^{2}$, Ratna Asmah Susidarti ${ }^{2}$ \\ ${ }^{1}$ Research Center of Chemistry, Indonesian Institute of Science (LIPI) \\ ${ }^{2}$ Cancer Chemoprevention Research Center (CCRC), Fakultas Farmasi Universitas Gadjah Mada, Yogyakarta \\ http://ccrc.farmasi.ugm.ac.id
}

\begin{abstract}
Areca (Areca catechu L.) seeds ethanolic extract (AE) exhibits antiproliferative activity and induces apoptosis on T47D and MCF-7 cells. This study aimed to verify AE safety using acute toxicity test to support its development as chemopreventive agent. Male Sprague Dawley Rat (Rattus norvegicus) age 8 weeks divided into five groups, one group of control treated with $0.5 \%$ CMC-Na only and four groups for treatment. Single dose in oral administration was done to test animal with various dose of $A E$ starts from lowest dose to highest dose expected toxic to all of test animal $(0.1 ; 0.72 ; 5.36$ and 10 gram $/ \mathrm{kgBW})$. Observation was done during 24 hours and continued for 14 days. The observation criteria were toxic symptoms, appearance and mechanism of toxic effect and pathology of vital organ. Histopathology analysis of some vital organs was done with Haematoxyllin\&Eosin (H\&E) staining. Toxic effect did not appear either on treatment groups or control group. Treatment of single dose of areca ethanolic extract, even in highest dose, did not cause the death of the animals. Therefore, observation extended to 14 days and terminated by necroption of the animals. All of groups did not show histopathological alterations in microscopic observation. Category of the potential toxicity of $A E$ is practically non-toxic, ie $10 \mathrm{~g} / \mathrm{kgBW}$. The result shows the safety of areca seed ethanolic extract which is important for its development as chemopreventive agent.
\end{abstract}

Keywords: Areca catechu, acute toxicity, rat.

\section{INTRODUCTIONS}

Acute toxicity is the degree of toxic effect of a compound on a specific test animals which occur within a short time after the single dose administration (Ecobichon, 1997). Areca catechu L., a family member of Arecaceae, is potential as chemotherapeutic agent because of its antioxidant and antimutagenic activity (Wang and Lee, 1996; Lee and Choi, 1999). Areca seeds contain alkaloids, such as arecoline (C8 H13 NO2), arekolidine, arekain, guvakolin, guvasine and isoguvasine. Ethanolic extract of areca seed contains condensed tannins, hydrolyzed tannins, flavan, phenolic compounds, gallic acid, gum, lignin, volatile and non-volatile oil, and salt (Wang and Lee, 1996). Areca seeds contain proanthocyanidin, a condensed tannin belonging to the flavonoids (Nonaka, 1989). Proanthocyanidin has antibacterial, antiviral, anticarcinogenic, antiinflammatory, anti-allergic, and vasodilation activity (Fine, 2000). Based on the previous studies, areca seed ethanolic extract and its fractions have cytotoxic effects and induce apoptosis against WiDr, T47D and MCF-7 cancer cells (Handayani, et al., 2008; Rahmi, et al., 2008; Meiyanto, et al., 2008 ${ }^{1}$; Meiyanto, et al., $2009^{1}$ ). In addition, the ethanolic extract of areca seed is also potentially synergistic when combined with chemotherapeutic agents (Meiyanto, et al., 2008²; Meiyanto, et al., $2009^{2}$ ). Therefore, these extract is expected to have maximum pharmacological effects and minimum toxicity effects. In this study, we observe the safety of areca seed ethanolic extract using acute toxicity test in vivo in normal mice.

\footnotetext{
*Corresponding author e-mail: anix_fa_83@yahoo.com
} 


\section{MATERIALS AND METHODS}

\section{Animals}

Normal and healthy male albino rats (Sprague Dawley), eight weeks old, each weighing 130-160 g. Animals were obtained from the Unite of Laboratory Animals, Faculty of Pharmacy, Gadjah Mada University.

\section{Chemicals}

Areca seed powder was purchased from BPTO Karanganyar and was extracted using absolute ethanol, CMC-Na (Merck), aquadest, $\mathrm{NaCl}, 10 \%$ formalin.

\section{In Vivo Experiments}

The rats were classified into 5 groups, each consisted of 5 rats:

Group I : was treated with $0.1 \mathrm{~g} / \mathrm{kg}$ bw AE Group II : was treated with $0.72 \mathrm{~g} / \mathrm{kg}$ bw AE Group III : was treated with $5.36 \mathrm{~g} / \mathrm{kg}$ bw AE Group IV : was treated with $10 \mathrm{~g} / \mathrm{kg}$ bw AE Group V : was treated with $0.5 \%$ CMC-Na (the vehicle of $\mathrm{AE}$ ) as control group.

Oral administration (p.o.) of $\mathrm{AE}$ was done through a single dose for each animal.

\section{Observations of Toxic Symptoms}

Intensive observations were done during the period of 24 hours after single dose administration of AE. The observation criteria were included: physical observations, the number of dead animals and organ histopathology. However, if none of the mice died within 24 hours, observations were continued until 14 days later.

\section{Histopathological Observation}

In the end of observation (after 14 day observation), each animal was sacrificed and its vital organs (hearth, liver, lung, kidney, spleen, and intestinal) were taken for macroscopic and microscopic observation. Furthermore, organs were rinse in aquadest and $\mathrm{NaCl}$, and were continued by preserved in $10 \%$ formalin for histopathological study. Treatment groups were compared with control group for all parameter.

\section{Statistical Analysis}

Rat body weight was observed and was analyzed every week until the end of study and expressed as mean \pm standard deviation. One way analysis of variance (ANOVA) and Tukey's post-hoc test was used to assess the statistical differences. $P$ values $<0.05$ was considered for statistically significance. The potency of toxicity of $\mathrm{AE}$ was determined using "lethal dose" $50 \%\left(\mathrm{LD}_{50}\right)$ parameter. The $\mathrm{LD}_{50}$ was stated according to the toxicity categories in Table I.

Table I. The range of $L D_{50}$ value based on its relative toxicity (Ecobichon, 1997).

\begin{tabular}{ll}
\hline Category of toxicity & LD $_{\mathbf{5 0}}(\mathbf{m g} / \mathbf{k g ~ b w})$ \\
\hline Very high toxic & $\leq 1.0$ \\
High toxic & $1.0-50$ \\
Moderate toxic & $50-500$ \\
slightly toxic & $500-5000$ \\
practically non toxic & $5,000-15,000$ \\
Harmless & $\geq 15,000$ \\
\end{tabular}

\section{RESULTS AND DISCUSSIONS}

\section{Qualitative Observation of Toxic Symptoms}

Toxic symptoms were intensively observed in the first 3 hours and were continued until 24 hours. Toxic symptoms observation were included changes in behavior, movement licking, scratching, wrinkles, nervous, writhing, reacting to stimuli (hyperactivity, passivity), cerebral and spinal reflex, pupil size, secretions, breathing, cardiac palpitations, skin condition, hair condition, and death. The results of the qualitative toxic symptoms in male rats for 24 hours after administration of $\mathrm{AE}$ showed that visible toxic symptoms were not detected in group I, II, V, and VI. Nevertheless, some of animal test in group III and IV showed behavioral changes such as biting the toes back, twitching, moving hyperactive then passive, irregular breathing and wheezing, gasping breathing, pyloerection, and arrhythmias (Table II). However, the toxic symptoms disappeared on the next days. The graphic of body weight during the observation in time period showed that the average weight growth of all of group was significantly not different among the test groups $(p<0.05)$ (Fig.1). 
Table II. Qualitative observation of toxic symptoms in male rats for $\mathbf{2 4}$ hours after oral administration of a single dose of AE.

\begin{tabular}{cllc}
\hline Group & \multicolumn{1}{c}{ Treatment } & N & Toxic symptom \\
\hline I & $0,1 \mathrm{~g} / \mathrm{kg} \mathrm{bw} \mathrm{AE}$ & 5 & - \\
II & $0,72 \mathrm{~g} / \mathrm{kg} \mathrm{bw} \mathrm{AE}$ & 5 & - \\
III & $5,36 \mathrm{~g} / \mathrm{kg} \mathrm{bw} \mathrm{AE}$ & 5 & + \\
IV & $10 \mathrm{~g} / \mathrm{kg} \mathrm{bw} \mathrm{AE}$ & 5 & + \\
V & $0.5 \% \mathrm{CMC} \mathrm{Na}$ & 5 & - \\
\hline
\end{tabular}

$(-)$ : toxic symptom was not detected; $(+)$ : toxic symptom was detected

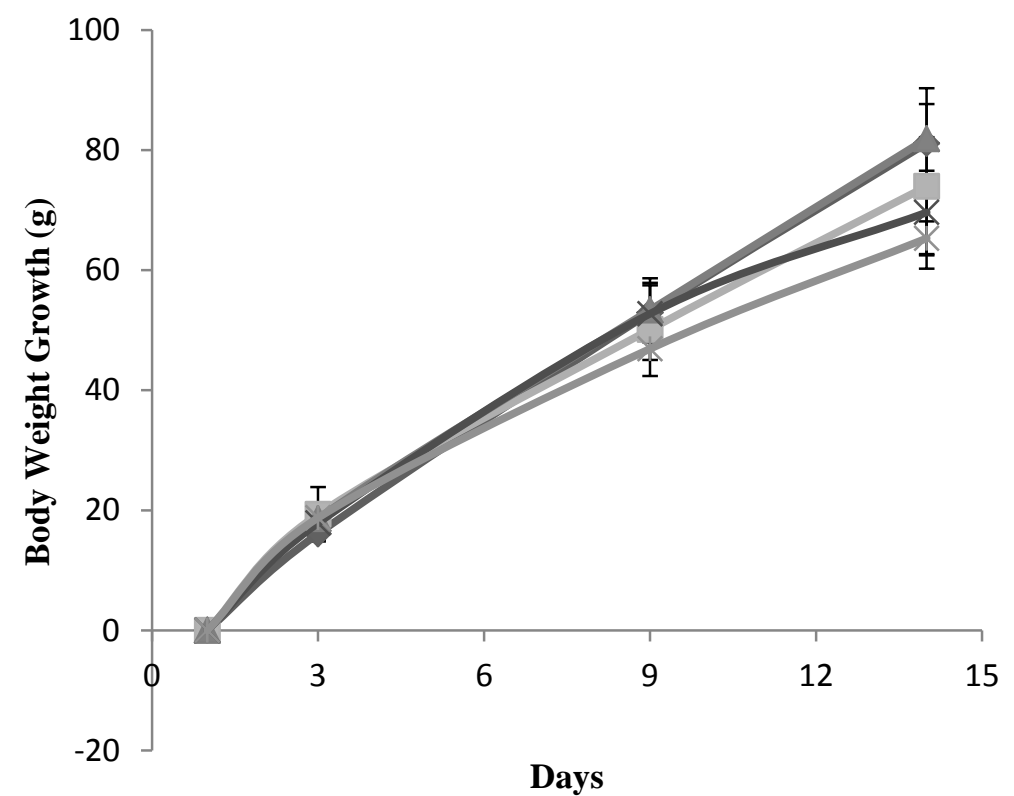

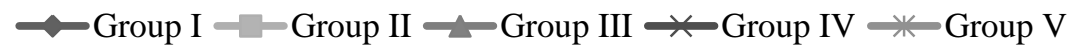

Figure I. Effect of AE on the body weight growth. Rats were weighed on the first day, the $3^{\text {rd }}$, ${ }^{\text {th }}$, and $14^{\text {th, }}$ then made an average. One way ANOVA was used to assess differences among treatment groups $(p<0.05)$.

\section{Histopathology Profile of Vital Organs}

The macroscopic data of the vital organs of rats that were observed was the physical appearances and organ weights. Macroscopic observation after administration of $\mathrm{AE}$ showed that the treatment groups were not different compared to control group. All of vital organs were normal, but lung organ was the exception. Lung in all of group was red, indicating inflammation. Because lung inflammation was observed in all group, it was not due to the $\mathrm{AE}$ treatment. 


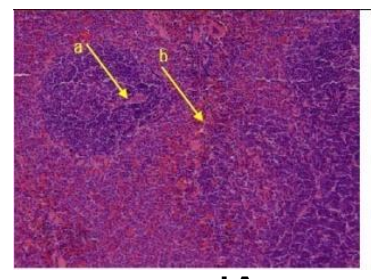

IA

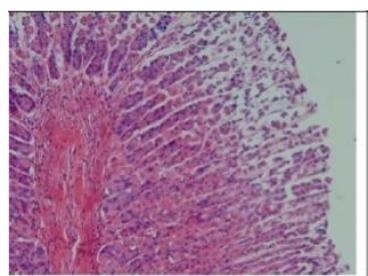

3A

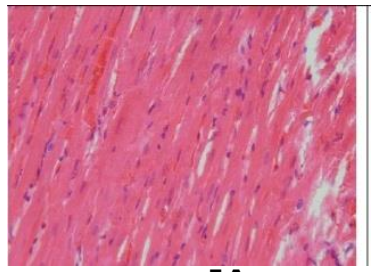

5A

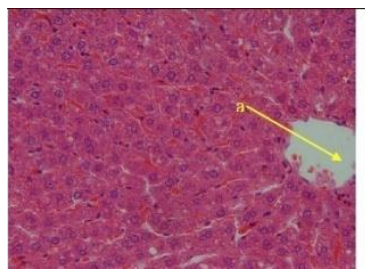

7 A

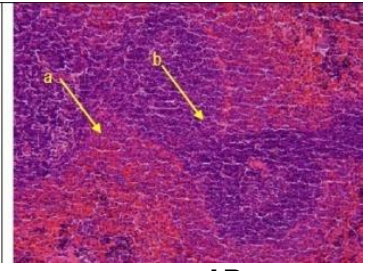

IB

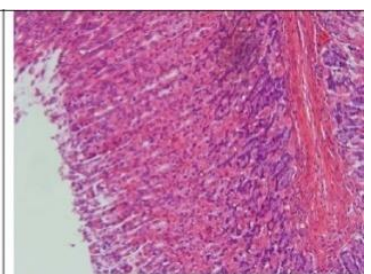

3B

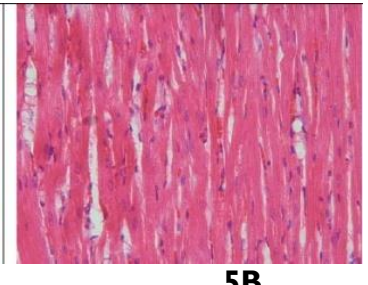

5B

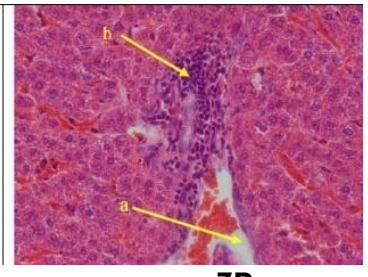

$7 B$

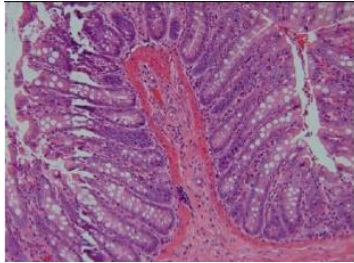

2A

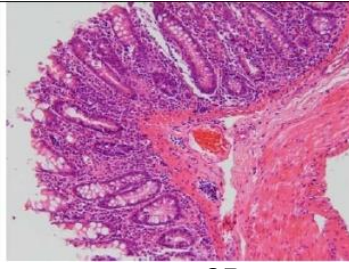

2B

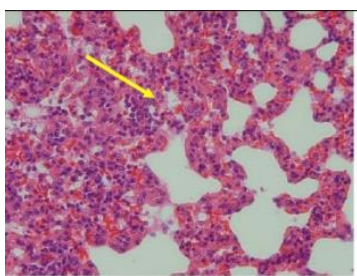

4 A

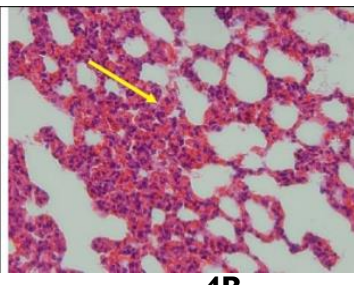

4B

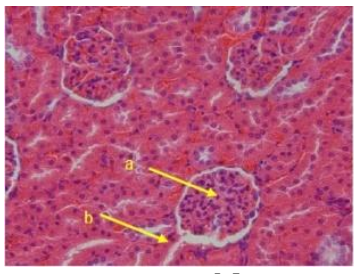

6A

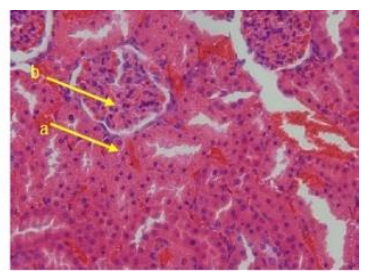

6B

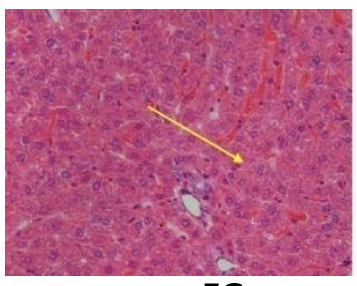

7C

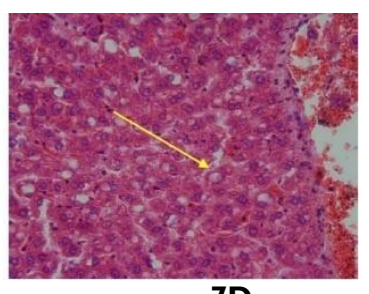

7D

Figure 2. Vital organs of rats in the high dose treatment group (group IV) showed microscopically almost not different compared to control (group V). (IA) spleen in group V, (IB) spleen in group IV, (2A) intestinal in group $V,(2 B)$ intestinal in group IV, (3A) gastric in group $V$, (3B) gastric in group IV, (4A) lung in group $V,(4 B)$ lung in group IV, (5A) heart in group $V$, (5B) heart in group IV, (6A) kidney in group V, (6B) kidney in group IV, (7A) normal liver in group $V$ showed a normal blood vessel (a), ( 7B ) liver vein in group IV, showed multifocal infiltration of inflammatory cells (b) of the blood vessels, ( 7C) liver in group $V$ did not show fat in the vacuole, (7D) liver in group IV, showed fat in the vacuole.

The results of microscopic observation (Table III) showed that the spleen on treatment and control groups were seen a normal red pulp and white pulp. The intestinal, stomach, heart and kidneys appeared normal. Lung organ was seen an inflammatory infiltration cell that was showed a great number of lymphocytes cells (colored purple), but both the treatment and the control group were not have difference appearance (Fig. 2(4A) and 2(4B)). The difference was showed in the liver organ, whereas in the highest dose of $\mathrm{AE}$ there were multifocal infiltrations, the presence of inflammatory cells around the blood vessels and the presence of fats in the vacuole (Fig. 2(7B) and 2(7D); Table III). From the microscopic observation, histopathological alterations of organs in the treatment groups were hardly found compared to control. 
Table III. Microscopic observation of the vital organs of rats after oral administration of the single dose of AE.

\begin{tabular}{cccccccc}
\hline Group & Liver & Kidney & Lung & Gastric & Heart & Spleen & Intestinal \\
\hline I & - & - & + & - & - & - & - \\
II & - & - & + & - & - & - & - \\
IV & - & - & + & - & - & - & - \\
V & + & - & + & - & - & - & - \\
\hline
\end{tabular}

$(-)$ : normal; (+) : hispathologycal changed

Because the ethanolic extract of areca seed (AE) shows its potency as chemopreventive agent, especially for combination application with chemotherapeutic agent, toxicity testing to guarantee the safety of $\mathrm{AE}$ needs to be done. Acute toxicity test results showed that at doses $5.36 \mathrm{mg} / \mathrm{kg}$ bw (group III) and $10 \mathrm{mg} / \mathrm{kg}$ bw (group IV), some rats had difficulty breathing, passive and there are actually hyperactive. However, the situation improved in 24 hours later. Based on the observation, AE at high dose possibly affects the respiratory and somatomotor system of rat but can recover quickly. Since histopathological data of treatment groups showed hardly different than control, except liver at the highest dose, then AE shows its safety to be consumed. The observation also showed that none of the mice died during the treatment. Then, the $\mathrm{LD}_{50}$ cannot be definitely stated. Therefore, the acute toxicity can only be expressed as "pseudo$\mathrm{LD}_{50}$ ", ie the largest dose that technically can still be given to the test animals. In this study, pseudo- $\mathrm{LD}_{50}$ of $\mathrm{AE}$ is $10 \mathrm{~g} / \mathrm{bw}$. In general, category of the potential toxicity of $\mathrm{AE}$ is practically non toxic according to table I, because pseudo- $\mathrm{LD}_{50}$ of $\mathrm{AE}$ is in the range of 5$15 \mathrm{~g} / \mathrm{kg}$ bw.

\section{ACKNOWLEDGEMENTS}

We thank drh. Retno Murwanti, MP., Ph.D. and Dr. Sitarina who give suggestion and analyzing the histological data.

\section{REFERENCES}

Ecobichon, D.J., 1997, The Basis of Toxicity Testing, $2^{\text {nd }}$ Edition, CRC Press, Boca Racon, New York, pp.43-60.

Fine, A.M., 2000, Oligomeric Proanthocyanidin Complexes: History, Structure, and
Phytopharmaceutical Applications, Altern Med. Rev., 5(2), |44-I5I.

Handayani, S., Meiyanto, E. and Susidarti, R.A., 2008, Areca (Areca catechu L.) Seeds Ethanolic Extract and Its Chloroform Fraction Induce Apoptosis and Decrease COX-2 Expression on WiDr Cells, Proceeding The International symposium on Molecular targeted Therapy, ISBN: 978-97995 107-6-I, Faculty of Pharmacy UGM, Pp. 67-74.

Lee, K.K. and Choi, J.D., 1999, The Effects of Areca Catechu L Extract on AntiInflammation and Anti-Melanogenesis, International Journal of Cosmetic Science, 2 I (4), 275-284.

Meiyanto, E., Susidarti, R.A., Handayani, S. and Rahmi, F., 2008', Ekstrak Etanolik Biji Buah Pinang (Areca catechu L.) Mampu Menghambat Proliferasi dan Memacu Apoptosis Sel MCF-7, Indonesian Journal of Pharmacy, I9(I), I2-19.

Meiyanto, E., Handayani, S., Susidarti, R.A., and Jenie, R.I., 2008², Areca (Areca catechu L.) Seeds Ethanolic extract and its chloroform fraction increase apoptotic effect of doxorubicin on human colon cancer cells, J. Bahan Alam Ind., 6(5), 169-175.

Meiyanto, E., Handayani, S., Susidarti, R.A., and Jenie, R.I., 2009', Chloroform fraction of Areca (Areca catechu L.,) Induces apoptosis an decreases $\mathrm{BCl}-2$ expression on MCF-7 cells, Mal. J. Pharm., I (7): 290-294.

Meiyanto, E., Handayani, S., Susidarti, R.A., and Septisetyani E.P., 2009², Areca (Areca catechu L.) Seeds Ethanolic Extract and Its Chloroform Fraction Increase Apoptotic Effect of Doxorubicin on MCF-7 Cells, j. ilm.Farm. Ind., 7(I), I318. 
Nonaka, G., 1989, Isolation and structure elucidation of tannins, Pure \& Appl. Chem, 6 I (3), 357-360.

Rahmi, F., Meiyanto, E., and Susidarti, R.A., 2008, Apoptosis effect of Areca catechu L. chloroform fraction on T47D cells, Proceeding The International Symposium on Molecular Targeted Therapy, ISBN:
978-979-95 I07-6-I, Faculty of Pharmacy UGM, pp. 75-82.

Wang, C.K. and Lee, W.H., 1996, Separation, Characteristics, and Biological Activities of Phenolics in Areca Fruit, J. Agric. Food Chem., 44(8), 2014-20I9. 